\title{
Repertoire Cloning of Lupus Anti-DNA Autoantibodies
}

\author{
Paul Roben, ${ }^{\star}$ Shana M. Barbas, ${ }^{\ddagger}$ Laura Sandoval, ${ }^{*}$ Jean-Michel Lecerf, ${ }^{\S}$ B. David Stollar, ${ }^{\S}$ Alan Solomon, \\ and Gregg J. Silverman* \\ *The Sam and Rose Stein Institute for Research on Aging and the Theodore Gildred Cancer Center, Department of Medicine, University \\ of California, San Diego, La Jolla, California 92093; ${ }^{\ddagger}$ The Department of Immunology, The Scripps Research Institute, La Jolla,

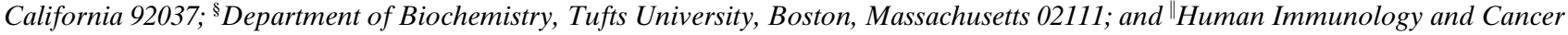 \\ Program, University of Tennessee Medical Center, Knoxville, Tennessee 37920
}

\begin{abstract}
To investigate the autoantibody repertoire associated with SLE, we have created phage display IgG Fab libraries from two clinically active SLE patients and from the healthy identical twin of one of these patients. The libraries from the lupus discordant twins were found to both include unusually large representations of the $\mathrm{V}_{\mathrm{H}} 5$ gene family. By panning with DNA, the SLE libraries each yielded IgG anti-doublestranded (ds) DNA autoantibodies, which are characteristic of lupus disease. These included a $\mathrm{V}_{\mathrm{H}} 5$ autoantibody from the affected twin, that has a targeted cluster of mutations that potentially improves binding affinity. The recovered IgG anti-dsDNA autoantibodies expressed the same idiotypes associated with the in vivo IgG anti-dsDNA response of the respective SLE donor. Heavy-light chain shuffling experiments demonstrated a case in which the in vitro creation of anti-dsDNA binding activity required restrictive pairing of a heavy chain with $V_{\lambda}$ light chains similar to those in circulating anti-dsDNA autoantibodies. By contrast, IgG anti-ds autoantibodies could not be recovered from the library from the healthy twin, or from shuffled libraries with heavy chains from the healthy twin. These repertoire analyses illustrate how inheritance and somatic processes interplay to produce lupus-associated IgG autoantibodies. (J. Clin. Invest. 1996. 98:2827-2837.) Key words: lupus • repertoire $\bullet$ autoantibody $\bullet$ anti-DNA $\bullet$ phage display
\end{abstract}

\section{Introduction}

High levels of circulating autoantibodies (autoAbs) $)^{1}$ are a hallmark of SLE, and animal models have confirmed that disease and premature death occur only after the skewing of the B cell repertoire toward autoreactivity $(1,2)$. While the pathophysi-

The data were presented in part at a conference entitled, "Immunoglobulin Gene Expression in Development and Disease," and appear in print (1995. Ann. NY. Acad. Sci. 764:565-566.).

Address correspondence to Gregg J. Silverman, Department of Medicine-0663, University of California, San Diego, 9500 Gilman Drive, La Jolla, CA 92093-0663, Phone: 619-534-5439; FAX: 619-5345399; E-mail: gsilverman@ucsd.edu

Received for publication 8 July 1996 and accepted in revised form 11 October 1996.

1. Abbreviations used in this paper: Ag, antigen; auto Ab, autoantibody; autoAg, autoantigen; H, heavy chain; L, light chain.

J. Clin. Invest.

(C) The American Society for Clinical Investigation, Inc. 0021-9738/96/12/2827/11 \$2.00

Volume 98, Number 12, December 1996, 2827-2837 ology of SLE is complex, there is much evidence to suggest that pathogenic autoantibodies are largely responsible for the organ damage, particularly the renal disease that is the primary cause of disability and death (3).

Circulating antibodies (Abs) that react with double-stranded (ds)DNA in vitro are diagnostic and prognostic markers for SLE. They also correlate with the development of lupus nephritis, especially diffuse proliferative glomerulonephritis $(4,5)$. While recent studies suggest that not all anti-dsDNA autoAbs are nephritogenic (reviewed in references 6 and 7), there is still considerable evidence that the transfer of certain anti-dsDNA autoAbs into healthy mice results in kidney deposition and renal damage $(8,9)$. Investigations of the role of disease-associated autoAbs in the pathophysiology of murine models of lupus have generally been much more successful than human studies. In large part, this is because human monoclonal autoAbs, and in particular the IgG autoAbs that are often implicated in organ damage, have been difficult to obtain from human donors using available cellular technologies. In addition, while autoimmunity-prone strains of mice display certain features of human disease, it is increasingly apparent that these mice also have idiosyncrasies that are not relevant to human pathophysiology.

In recent years, an alternative means for sampling an $\mathrm{Ab}$ response, known as repertoire cloning (10), has been developed. This approach enables the generation of mAbs of defined specificity, by the molecular cloning of expressed $\mathrm{Ab}$ heavy $(\mathrm{H})$ and light $(\mathrm{L})$ chains genes that are isolated directly from lymphocytes, which are selected based on binding specificity after in vitro expression. We have recently reported our use of repertoire cloning for the recovery of $\mathrm{IgG}$ anti-dsDNA autoAbs from a SLE patient (11). We have focused on autoAbs to dsDNA, because of the evidence of their role in SLE pathogenesis, and because there is a large body of data regarding these autoAbs from murine and human B cell lines that enable comparisons regarding genetic, immunochemical, and functional features.

Our previous report included a library from an active lupus patient, SI. ELISA, surface plasmon resonance determinations, and Crithidia immunofluorescence assays documented that high affinity IgG autoAbs to dsDNA can be recovered from a phage-display Fab library made from the peripheral blood lymphocytes of an SLE patient (11).

In the current study we extend these studies to include additional IgG Fab libraries constructed from the peripheral blood lymphocytes of a set of identical twins discordant for SLE. By panning on human dsDNA, IgG anti-dsDNA autoAbs could be recovered only from the library of an SLE patient with high circulating levels of this type of autoAb, and not from a library from the healthy identical twin of one of these patients. Using antigen (Ag)-binding assays, tests for three different cross-reactive idiotypes, $\mathrm{V}$ region DNA se- 
quence analysis and immunoglobulin chain shuffling studies, we characterized the anti-DNA autoAbs obtained from these libraries, and demonstrated their relationship to the autoAbs present in the circulation of the two SLE donors.

\section{Methods}

Creation of combinatorial Ig libraries. The two female SLE patients, SI (previously reported [11]) and AA, were diagnosed by the criteria of the American Rheumatism Association (ARA), and used as donors in the generation of combinatorial libraries. These patients had high circulating levels of IgG Abs to dsDNA, and other clinical and serologic features of classical SLE. Patient AA was a nulliparous 26-yrold Caucasian female, who initially presented with malar rash, nondeforming polyarthritis, hypertension, mild renal insufficiency, proteinuria, active urinary sediment, anemia, and thrombocytopenia. She developed biopsy-proven diffuse membranoproliferative lupus nephritis that progressed to complete renal failure shortly after sample donation. AA had shared an amniotic sac and placenta with an identical twin, BB, who was gravida 2 , para 2 , had no history or clinical findings consistent with SLE or other active medical problems. Despite a high titer antinuclear Abs, BB did not have significant levels of IgG autoAbs to dsDNA. Neither of the twins had detectable anticentromere, Sm, RNP, or rheumatoid factor autoAbs. After informed consent, peripheral blood from these subjects was obtained as the source of mRNA for generation of IgG1 libraries, the predominant subclass of lupus anti-dsDNA Abs (12). As previously described (13-16), PCR was used to rescue and clone Ab genes from human tissue into the phage display vector, pCOMB3H (gift of Dr. C.F. Barbas, The Scripps Research Institute, La Jolla, CA), to construct each library. In a library, Ab genes are cloned within the phage-mid vector, and surface display phagemid clones are then selected based on $\mathrm{Ab}$ binding specificity. To construct the AA and BB libraries, a previ- ously described panel of $\mathrm{V}_{\mathrm{H}}$ and $\mathrm{V}_{\mathrm{L}}$ first framework region specific primers (16) were supplemented with primers to ensure representation of newly reported $\mathrm{V}_{\lambda}$ genes: VL1b/5, 5'-CAG TCT GAG CTC ACT CAG CCA CC-3'; VL9, 5'-CAG TCT GAG CTC ACT CAG CCT CCC-3'; VL $^{\prime}, 5^{\prime}$-TCC TAT GAG CTC ACT CAG CCA CCC3', VL8' 5' -CAG CTT GAG CTC ACT CAA TCG CCC-3'; VL7, 5' CAG GTT GAG CTC ACT CAA CCG CCC-3'. The PCR conditions have previously been described $(15,16)$. In an effort to make comparable libraries, equal amounts of the 660-700 bp DNA band from each amplification was included in the AA and BB libraries. The resultant libraries contained $>2 \times 10^{7}$ colony forming units (cfu). Individual pCOMB3H clones were designated according to its library/donor source (SI, AA, or BB).

Antibody selection. To avoid loss of phage-Fabs through binding to bacterial DNA (or RNA) in the cultures, $2 \mathrm{mg}$ of bovine pancreatic DNAse (Sigma Chemical Co., St. Louis, MO), 2 mg of Type II-A RNAse (Sigma Chemical Co.) and hydroxyapatite (Sigma Chemical Co.) were included in the medium for phage growth before precipitation and purification (11). As previously described, for selection of DNA-specific clones, the SI library was panned against human placental DNA (Sigma, Chemical Co.) which contains both ss and dsDNA (11), while the AA and BB libraries were panned against placental DNA optimized for dsDNA content (see below). DNA was immobilized on microtiter wells by coating at $10 \mu \mathrm{g} / \mathrm{ml}$ in PBS and air drying. Before use, wells were rinsed twice with $\mathrm{dH}_{2} \mathrm{O}$ and blocked with $3 \%$ BSA-PBS. For each round of selection, two wells were filled with 50 $\mu l$ of phage library containing $10^{11} \mathrm{cfu}$ in PBS, and incubated for $2 \mathrm{~h}$ at $37^{\circ} \mathrm{C}$. After wells were extensively washed, binding phage were eluted with glycine- $\mathrm{HCl}, \mathrm{pH} 2.5$, and rapidly neutralized with $2 \mathrm{M}$ Tris-base. Phage were amplified and rescued prior to each round of panning.

Chain shuffling experiments. The AD4-37 anti-DNA Ab is representative of one the two major Ab sets selected from the IgG Fab $\kappa / \lambda$ library from the SLE-affected twin, AA, after four rounds of selec-

Table I. Idiotypic Reactivities and Structural Homologies of Recombinant Lupus IgG Anti-dsDNA Autoantibodies

\begin{tabular}{|c|c|c|c|c|c|c|c|c|c|c|}
\hline & \multicolumn{6}{|c|}{$V_{H}$ gene usage } & \multicolumn{4}{|c|}{$V_{L}$ gene usage } \\
\hline & 18/2 CRI* & B6 CRI & $\mathrm{V}_{\mathrm{H}}$ family & Nearest $\mathrm{V}_{\mathrm{H}^{\ddagger}}$ & $\mathrm{V}_{\mathrm{H}}$ DNA & $\mathrm{J}_{\mathrm{H}}$ & VגIIIa CRI & $\mathrm{V}_{\mathrm{L}}$ family & Nearest $V_{L}$ & $\mathrm{~V}_{\mathrm{L}}$ DNA \\
\hline \multicolumn{11}{|l|}{ AA library } \\
\hline AD4-37 & - & + & 3 & 1.9III/V3-30 & 99.3 & $\mathrm{~J}_{\mathrm{H}} 3 \mathrm{~b}$ & + & $\lambda 3$ & III.1 & 99.2 \\
\hline AD4-18 & - & - & 5 & $\mathrm{~V}_{\mathrm{H}} 251 / \mathrm{V} 5-51$ & 91.9 & $\mathrm{~J}_{\mathrm{H}} 5 \mathrm{a}$ & - & $\lambda 2$ & lalh2* & 85.4 \\
\hline \multicolumn{11}{|c|}{$\begin{array}{l}\text { AA H-L chain shuffled libraries } \\
\text { With AD4-37VL } \text { S }^{\S}\end{array}$} \\
\hline AAD4-HC2 & - & - & 3 & Cos 6/V3-74\| & 92.9 & $\mathrm{~J}_{\mathrm{H}} 3 \mathrm{~b}$ & + & $\lambda 3$ & III.1 & 99.2 \\
\hline AAD4-3/3 & - & - & 3 & $\mathrm{p} 1$ & 88.2 & $\mathrm{~J}_{\mathrm{H}} 5 \mathrm{~b}$ & + & $\lambda 3$ & III.1 & 99.2 \\
\hline \multicolumn{11}{|c|}{ With AD4-37VH } \\
\hline ABD4-lam2 & - & + & 3 & 1.9III/V3-30 & 99.3 & $\mathrm{~J}_{\mathrm{H}} 3 \mathrm{~b}$ & - & $\lambda 2$ & DPL13 & 93.6 \\
\hline ABD4-lam3 & - & + & 3 & 1.9III/V3-30 & 99.3 & $\mathrm{~J}_{\mathrm{H}} 3 \mathrm{~b}$ & - & $\lambda 1$ & IGLV1S2 & 99.3 \\
\hline \multicolumn{11}{|l|}{ SI library ${ }^{\mathbb{I}}$} \\
\hline SI-32 & + & - & 3 & $\mathrm{~V}_{\mathrm{H}} 26 / \mathrm{V} 3-23$ & 97.8 & $\mathrm{~J}_{\mathrm{H}} 4 \mathrm{~b}$ & - & $\lambda 3$ & IGLV3S1 & 99.6 \\
\hline SI-13 & + & - & 3 & $\mathrm{~V}_{\mathrm{H}} 26 / \mathrm{V} 3-23$ & 91.6 & $\mathrm{~J}_{\mathrm{H}} 4 \mathrm{~b}$ & - & $\lambda 2$ & DPL1 & 96.1 \\
\hline SI-1 & + & - & 3 & GL-6 & 97.8 & $\mathrm{~J}_{\mathrm{H}} 4 \mathrm{~b}$ & - & кIII & kv325 & 97.6 \\
\hline SI-40 & - & + & 3 & $\operatorname{Cos} 3$ & 98.9 & $\mathrm{~J}_{\mathrm{H}} 6 \mathrm{~b}$ & - & $\lambda 1$ & $\operatorname{lv} 1042$ & 95.7 \\
\hline SI-22 & - & + & 3 & $\operatorname{Cos} 3$ & 97.8 & $\mathrm{~J}_{\mathrm{H}} 6 \mathrm{~b}$ & - & $\lambda 1$ & lv1042 & 98.8 \\
\hline SI-39 & - & - & 1 & DP-75 & 94.9 & $\mathrm{~J}_{\mathrm{H}} 6 \mathrm{~b}$ & - & кIII & kv325 & 97.6 \\
\hline
\end{tabular}

*CRI expression were determined by direct binding and inhibition ELISA. ${ }^{*}$ The closest known $\mathrm{V}_{\mathrm{H}}$ or $\mathrm{V}_{\mathrm{L}}$ germline gene is indicated. Calculations of homology omit the contribution of the upstream FR1 primer. ${ }^{\S}$ The clones that begin with AAD were selected using the $\mathrm{V}_{\mathrm{L}}$ region of the AD4-37 clone and a library of $\mathrm{H}$ chain genes from the affected twin, AA. The clones that begin with ABD were selected with the $\mathrm{V}_{\mathrm{H}}$ region of AD4-37 and a library of L chain genes from the healthy twin, BB. "Cos6 is an allele of V3-74 (I. Tomlinson, personal communication). "The SI library and these DNA antibodies have previously been described (11). 
tion with human placental dsDNA (Table I). To evaluate the relative contribution and/or permissiveness of the $\mathrm{H}$ and $\mathrm{L}$ chains of the AD4-37 Ab for the DNA binding specificity, four additional shuffled libraries were created. Using the same restriction sites used for cloning, a shuffled library was created in which the $\mathrm{H}$ chain gene of AD4-37 replaced all $\mathrm{H}$ chain genes paired with the BB-к (healthy twin's) library of diverse $\mathrm{L}$ chains. We created a separate shuffled library by pairing this same $\mathrm{H}$ chain gene of AD4-37 with the BB- $\lambda$ library of diverse L chains. A third library was created, in which the $\mathrm{L}$ chain gene of AD4-37 was paired with the BB library of diverse $\mathrm{V}_{\mathrm{H}^{-}}$-gamma rearrangements. A fourth library was also created in which this same L chain gene of AD4-37 was paired with the AA (affected twin's) library of diverse $\mathrm{V}_{\mathrm{H}^{-}}$gamma genes. We also attempted to create a library in which the $\mathrm{H}$ chain gene of AD4-37 replaced all of the $\mathrm{H}$ chain genes paired with the AA library of diverse $\mathrm{V}_{\mathrm{L}}$ gene rearrangements, however multiple attempts at phage selection with dsDNAcoated wells yielded only clones with deleted $\mathrm{L}$ chain genes.

Colony hybridization to survey of $V_{H}$ family diversity. To survey $\mathrm{V}_{\mathrm{H}}$ chain diversity within the $\mathrm{pComb3 \textrm {H }}$ clones, the AA and BB libraries were screened by hybridization with $\mathrm{V}_{\mathrm{H}}$ family-specific framework region derived 30-40-mer oligonucleotides, as previously reported (16), and with oligonucleotides from the CDR1 of the AD4-37V $\mathrm{V}_{\mathrm{L}}, 5^{\prime}$ GAT AAA TTG GGG GAT AAA TAT 3'; the CDR3 of the AD4$18 \mathrm{~V}_{\mathrm{L}}, 5^{\prime}$ CCA GTT GTA CCG CCC GGG TAG T 3; and the CDR3 of the AD4-37V $\mathrm{V}_{\mathrm{H}}, 5^{\prime}$ CCA AAG CCC TCG GTA CTA TCA T 3'.

DNA sequence determination. The nucleotide sequences of the $\mathrm{V}_{\mathrm{H}}$ and $\mathrm{V}_{\mathrm{L}}$ regions were determined by automated sequencing (Applied Biosystems, Foster City, CA), and each was determined at least three times using two different primers with previously described primers $(15,16)$. Analyses used Macvector 4.0 (IBI, New Haven, CT) and GCG (Madison, WI) software packages, with comparison to GENBANK and the V Base Directory. ${ }^{2}$

Antibody binding assays. The (ds)DNA binding activity of serum and cloned Abs was evaluated in an ELISA format that produces results that have been correlated with Crithidia lucilae immunofluorescence and surface plasmon resonance determinations of native DNA binding (11). High molecular weight human placental DNA was used (17). Because immobilization of the dsDNA on the solid phase may expose determinants associated with ssDNA, all Abs were evaluated using both ssDNA and dsDNA precoats to better assess binding specificity (11). For these assays, dsDNA and ssDNA were prepared as previously described, and microtiter wells (Cat. No. 3690; Costar Corp., Cambridge MA) were coated with $0.5 \mu \mathrm{g}$ of DNA per well in $50 \mu \mathrm{l}$ water and dried overnight. Wells were washed 10 times with $0.05 \%$ Tween-BBS and blocked for $1 \mathrm{~h}$ at $37^{\circ} \mathrm{C}$ with $3 \%$ BSA in PBS. Wells were then emptied and filled with serum samples diluted in $1 \%$ BSA-PBS and incubated for $2 \mathrm{~h}$ at $37^{\circ} \mathrm{C}$. Wells were then washed 10 times with Tween 20-BBS, and incubated for $1 \mathrm{~h}$ at room temperature with horseradish peroxidase (HRP) conjugated affinity purified goat anti-human IgG or IgM (Boehringer-Mannheim, Indianapolis, IN) diluted 1:2,000 in 1\% BSA-PBS. Plates were washed and developed with the TMB substrate (Kirkegaard and Perry Labs, Gaithersburg, $\mathrm{MD})$ and the OD (450-650 nm) determined. For other binding assays, BSA, methyl-BSA, actin, cardiolipin, ovalbumin, dextran sulfate (Sigma Chemical Co.), tetanus toxoid (Connaught Labs, Swiftwater, PA), or human IgG Fc fragments (Jackson Labs, West Grove, PA) were substituted using the same conditions. In all studies, samples were designated as positive if they were at least three SD above highest value obtained for 32 healthy adult controls.

Idiotype assays. The murine IgG1 mAb, B6, identifies the products of genes and alleles related to only two of the $\sim 20$ functional germline $\mathrm{V}_{\mathrm{H}} 3$ gene segments (18)(V Base Sequence Directory),

2. A Database of Human Immunoglobulin Variable Region Genes. I.M. Tomlinson, S.C. Williams, S.J. Corbett, J.P.L. Cox, and G. Winter. MRC Centre for Protein Engineering, Hills Road, Cambridge CB2 2QH, United Kingdom. which include the 1.9III/V3-30 and Cos3 genes ([19] and G.J. Silverman, unpublished observations). The anti-18/2 CRI, is identified by the absorbed rabbit serum, termed Ra504, which was induced by immunization with 18/2, a human IgM anti-ssDNA Ab encoded by an unmutated $\mathrm{V}_{\mathrm{H}} 26 / \mathrm{V} 3-23$ gene (20-22). An idiotype expressed on $\mathrm{mAb}$ $18 / 2$ has previously been associated with lupus autoAbs with antiDNA and other self-specificities $(22,23)$. The murine $\operatorname{IgG}_{2 \mathrm{~b}} \mathrm{mAb}$, termed 22-15D11 or $\lambda$ IIIIa, recognizes a subset within human $\mathrm{V}_{\lambda} \mathrm{III} \mathrm{L}$ chains (24), and this idiotype was associated with an anti-IgG autoAb (rheumatoid factor) from a rheumatoid arthritis patient (25).

Assays of idiotype expression were designed to identify the idiotype expressed on serum IgG autoAbs, and avoid detection of the idiotype on the parallel set of Abs that do not possess autoreactivity. In a sensitive direct binding ELISA, microtiter wells were coated overnight at $4^{\circ} \mathrm{C}$ with highly purified dsDNA at $10 \mu \mathrm{g} / \mathrm{ml}$, blocked with $3 \% \mathrm{BSA}$ in PBS, and incubated for $4 \mathrm{~h}$ at room temperature (RT) with either the human monoclonal Fab at $1 \mu \mathrm{g} / \mathrm{ml}$, or a serum that was serially diluted beginning at 1:100. Thereafter, wells were washed and incubated for $1 \mathrm{~h}$ at $37^{\circ} \mathrm{C}$ with the antiidiotype or an equivalent concentration of an isotype control, then washed and incubated with the appropriate HRP-labeled anti-rabbit IgG or mouse IgG (Boehringer-Mannheim Biochemicals), then developed.

Reactive sera were evaluated in inhibition studies, in which sera at a fixed dilution (1/800) in the linear portion of the curve were preincubated for $1 \mathrm{~h}$ with a saturating concentration (up to $40 \mu \mathrm{g} / \mathrm{ml}$ ) of the antiidiotypic $\mathrm{Ab}$ (or an isotype control). These samples were subsequently incubated in dsDNA precoated plates for $4 \mathrm{~h}$ at RT. Plates were washed and binding was detected with HRP-tagged anti-human $\mathrm{IgG}, \mathrm{IgM}, \kappa$ or $\lambda \mathrm{Ab}$ (Tago, Burlingame, CA). Serial dilutions of the same serum without inhibitor were used for quantitation. For direct antiidiotype assays, wells were instead precoated with an antiidiotypic $\mathrm{Ab}$ at $10 \mu \mathrm{g} / \mathrm{ml}$, then developed as described above.

\section{Results}

Selection and characterization of autoantibodies from phage display libraries. Human placental dsDNA was used as the selection $\mathrm{Ag}$ for Abs from the IgG Fab library from each twin. Significantly, anti-dsDNA Abs were successfully selected from the library from the affected twin, AA (Fig. 1) but despite multiple attempts using the same conditions we were unable to se-

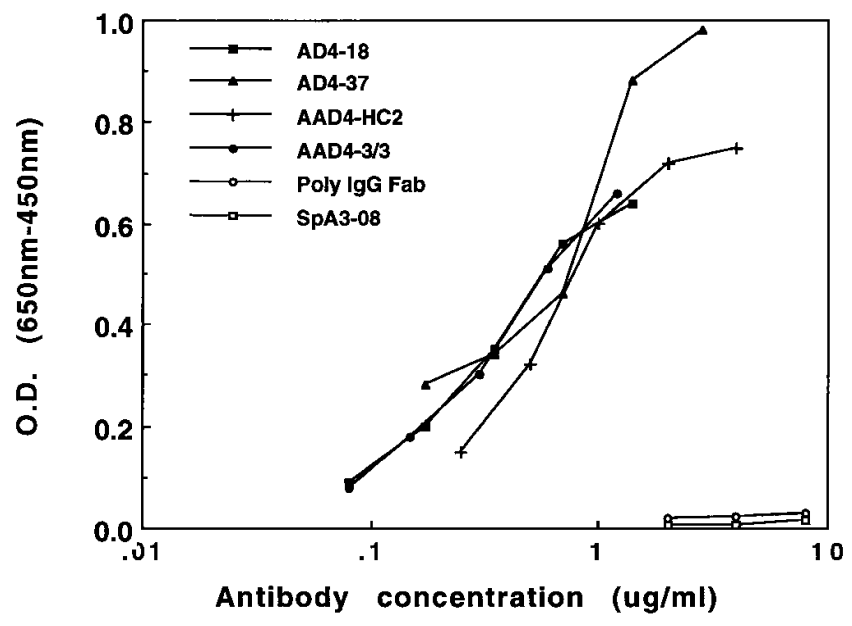

Figure 1. The DNA binding activities of select autoantibodies. Binding activities of the purified monoclonal IgG Fab for dsDNA precoated ELISA plates are compared with adult polyclonal IgG Fab (Poly IgG Fab), and a control monoclonal IgG Fab (SpA3-08)(15). The binding activities of the autoAbs from the SI library have previously been reported (11). 


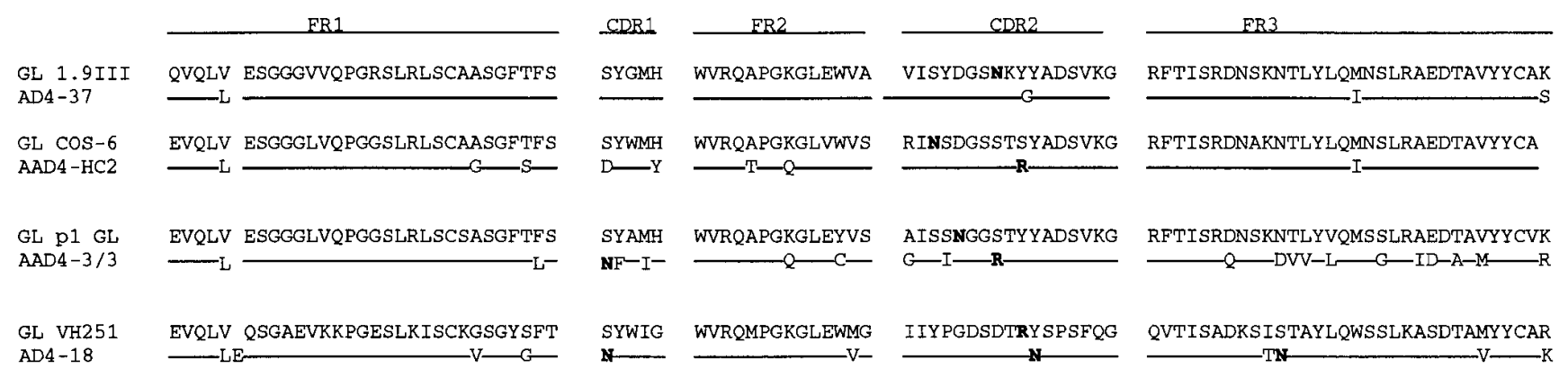

Figure 2. $\mathrm{V}_{\mathrm{H}}$ regions of autoantibodies. The deduced amino acid sequences of the $\mathrm{V}_{\mathrm{H}}$ regions of IgG Fab anti-dsDNA Abs are displayed. Sequences are compared to the closest known germline gene. Identity is demonstrated by a horizontal line, with amino acid differences indicated. These sequence data are available from EMBL/GenBank/DDBJ under accession numbers U70232, U70233, U70236, and U70238.

lect Abs with dsDNA binding activity from the library of the healthy twin, BB. Abs with ssDNA binding activity could be derived from both libraries (not shown).

DNA sequence analysis of the $\mathrm{V}_{\mathrm{H}}$ regions of 10 randomly selected plasmid clones from the AA library obtained after four rounds of selection on DNA coated wells demonstrated the presence of only two distinct $\mathrm{V}_{\mathrm{H}}$ rearrangements, represented by the AD4-37 and AD4-18 mAbs (Table I, Figs. 2 and 3). V gene analysis of these two Abs revealed intriguing structural and genetic features. Strikingly, the $\mathrm{H}$ and $\mathrm{L}$ chain genes of the AD4-37 Ab are only minimally mutated, differing by only two point mutations from known germline genes, i.e., $\mathrm{V}_{\mathrm{H}}$ (1.9III/ V3-30) and $V_{L}$ (III.1), respectively (Figs. 2 and 4, Table I). In an independent isolate we identified a $\mathrm{V}_{\mathrm{H}}$ gene rearrangement that was identical except for the incorporation of the sequence of a different upstream FR1 primer, suggesting that the AD4$37 \mathrm{~V}_{\mathrm{H}}$ sequence variations from the $\mathrm{V} 3-30$ germline gene are probably not cloning artifacts. This same germline $\mathrm{V}_{\lambda}$ III gene and $\mathrm{a}>97 \%$ homologous $\mathrm{V}_{\mathrm{H}} 3$ gene segment are paired in an IgM anti-phospholipid autoAb produced by cellular techniques (26). This exact $V_{H}$ gene segment in germline configuration, paired with a germline encoded $\mathrm{V}_{\lambda} \mathrm{I}$ light chain, was previously identified in an IgM anti-DNA autoAb from a hybridoma (27).

The AD4-18 anti-dsDNA autoAb is encoded by a $\mathrm{V}_{\mathrm{H}} 5$ gene with a total of 12 mutations including 7 replacement mutations. Interestingly, this $\mathrm{V}_{\mathrm{H}} 5$ gene has a cluster of three point mutations in two adjacent codons in the tip of the FR3 loop that changes the germline isoleucine-serine to newly create threonine-asparagine (Fig. 2), at a mutational hotspot (28).
The $\mathrm{L}$ chain of the AD4-18 Ab is most homologous to a $\mathrm{V}_{\mathrm{L}}$ gene segment in the $\mathrm{V}_{\lambda}$ II gene family termed DPL7 (29) (Fig. 4).

Surveys of $V$ gene usage in the libraries by colony hybridization. To evaluate independently the molecular diversity in the $\mathrm{AA}$ and $\mathrm{BB}$ libraries, surveys were performed with $\mathrm{V}_{\mathrm{H}}$ gene family (16) and V gene-specific oligonucleotide probes (Table II). The IgG libraries from the twins had almost identical distribution of $\mathrm{V}_{\mathrm{H}}$ families. The large $\mathrm{V}_{\mathrm{H}} 1, \mathrm{~V}_{\mathrm{H}} 3$, and $\mathrm{V}_{\mathrm{H}} 4$ families, which are commonly expressed in the peripheral repertoires of healthy adults $(15,16,30,31)$, were well represented (Table II). However, more than one third of the gamma rearrangements in both the AA and BB libraries derived from the $\mathrm{V}_{\mathrm{H}} 5$ gene family, while the $\mathrm{V}_{\mathrm{H}} 5$ family is the source of $<1 \%$ of the rearrangements in several libraries made from the healthy adults constructed with the same methods ([15, 16] and G.J. Silverman, unpublished observations).

Almost all of the colonies in the AA library obtained following four pannings with dsDNA were derived from either the $\mathrm{V}_{\mathrm{H}} 3$ or $\mathrm{V}_{\mathrm{H}} 5$ families $(92 \%)$ (Table II), which was consistent with the DNA sequence results (see above). Hybridization studies also confirmed that after panning, the $\mathrm{V}_{\mathrm{H}} \mathrm{AD} 4-37$, $\mathrm{V}_{\mathrm{L}} \mathrm{AD} 4-37$, and $\mathrm{V}_{\mathrm{H}} \mathrm{AD} 4-18$ genes are highly represented ( $\geq 20 \%$ ) amongst their respective rearrangements. Compared with the unselected AA library, representation of each of these specific $\mathrm{V}_{\mathrm{H}}$ and $\mathrm{V}_{\mathrm{L}}$ rearrangements was increased 10- to 14-fold in the dsDNA-selected library $(P<0.05$, by chi-square analysis).

By contrast, panning with dsDNA did not appreciably change the representation of the different $V_{H}$ families in the

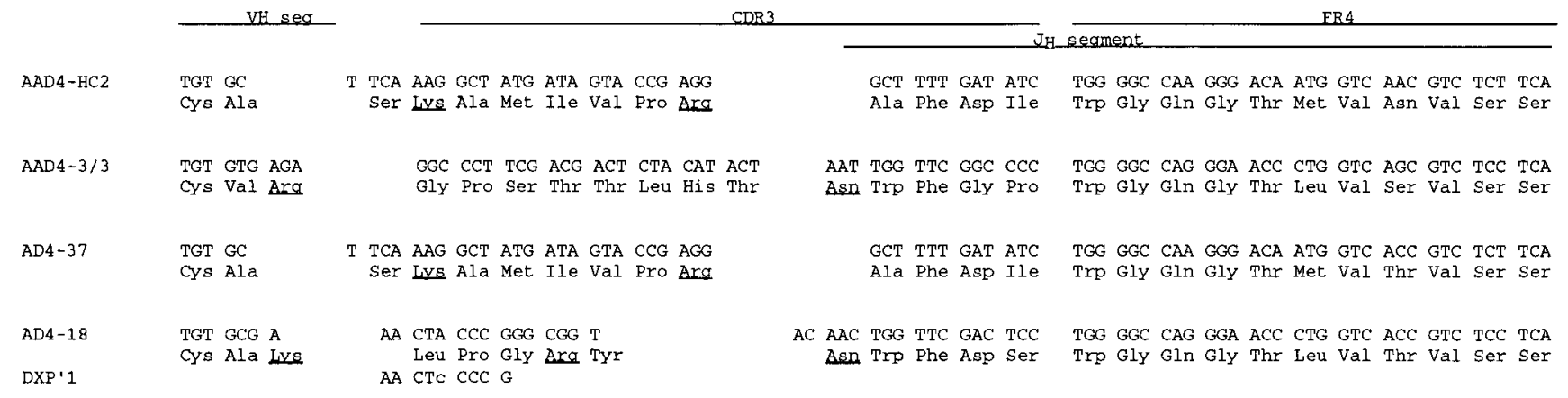

Figure 3. $\mathrm{V}_{\mathrm{H}} \mathrm{CDR} 3$ sequences of anti-dsDNA antibodies. The $\mathrm{V}_{\mathrm{H}}$ regions of AD4-37 and AAD4-HC2 are shown to share identical CDR3 and FR4 regions, despite employing distinct $\mathrm{V}_{\mathrm{H}} 3$ gene segment contributions. Only for the $\mathrm{V}_{\mathrm{H}} \mathrm{AD} 4-18$ was significant homology detected with known $\mathrm{D}_{\mathrm{H}}$ and DIR genes. The same nonamer sequence in $\mathrm{V}_{\mathrm{H}} \mathrm{AD} 4-18$ had one nucleotide mismatch the same sequence in dxp'1 and d21. 


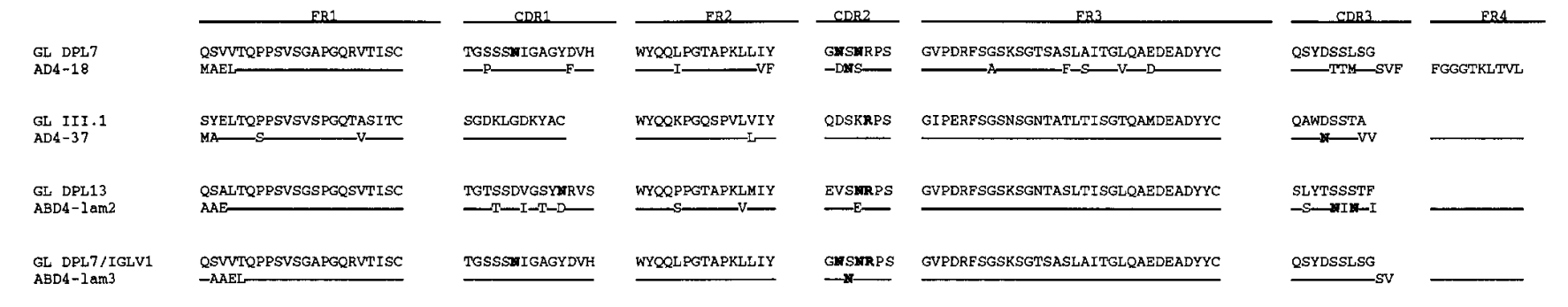

Figure 4. $\mathrm{V}_{\mathrm{L}}$ regions of anti-DNA antibodies. The deduced amino acid sequences of the $\mathrm{V}_{\mathrm{L}}$ regions of IgG Fab anti-dsDNA Abs are displayed. Sequences are compared to the closest known germline gene. Identity is demonstrated by a horizontal line, with amino acid differences indicated. These sequence data are available from EMBL/GenBank/DDBJ under accession numbers U70234, U70235, U70237, and U70239.

BB libraries (Table II). While control studies documented dual $\mathrm{V}_{\mathrm{H}} / \mathrm{V}_{\mathrm{L}}$ genes cloned and Fab displayed on the surface of phage in these libraries, these pannings of the $\mathrm{V}_{\mathrm{H}}$ BB libraries did not select for Abs with significant dsDNA binding activity, and did not select for phagemid clones with related or restricted $\mathrm{V}_{\mathrm{H}}$ gene DNA sequences (not shown).

Selection and characterization of autoantibodies from shuffled libraries. To evaluate the relative contribution of particular $\mathrm{H}$ and $\mathrm{L}$ chains to DNA binding, the Ab V genes of AD4-37 were individually paired with libraries of reciprocal chains (Table III). Panning of the library composed of the $\mathrm{V}_{\mathrm{H}} \mathrm{AD} 4-37$ gene (originally isolated from the AA library) paired with the diverse $\kappa / \lambda$ AA library selected for Abs with dsDNA binding activity. Hybridization studies revealed selection for clones with the $\mathrm{V}_{\mathrm{L}}$ AD4-37 CDR3 but also with certain other $\lambda$-type $\mathrm{L}$ chains (Table III). However, in several panning experiments, no autoAbs with $\kappa$-type $L$ chains were selected from this library.

The $\mathrm{V}_{\mathrm{H}} \mathrm{AD} 4-37$ gene was also paired separately with a diverse $\kappa$ gene library and a diverse $\lambda$ gene library from $B B$, the healthy twin. Repeated attempts at panning the $\mathrm{V}_{\mathrm{H}} \mathrm{AD} 4-37$ gene-BB diverse $\kappa$ gene rearrangement shuffled library were completely unsuccessful at recovering Abs with dsDNA bind- ing activity. In contrast, Abs with dsDNA binding activity were selected from the $\mathrm{V}_{\mathrm{H}} \mathrm{AD}$ 4-37 gene- $\mathrm{BB}$ diverse $\lambda$ gene rearrangement shuffled library. Hybridization studies did not detect the $\mathrm{V}_{\mathrm{L}} \mathrm{AD}$ 4-37 rearrangement in these BB L chain-containing libraries before or after panning (Table III). Sequence analysis of individual anti-dsDNA autoAb clones demonstrated selection of other $\mathrm{L}$ chain rearrangements exemplified by ABD4-lam3, which derives from the $V_{\lambda} I$ family, and the ABD4-lam2 (Fig. 4 and Table III) that derives from the $V_{\lambda} I I$ gene family associated with the lupus idiotype 8.12 (32). These studies suggest that the creation of dsDNA binding activity can only occur when the $\mathrm{H}$ chain from the $\mathrm{V}_{\mathrm{H}}$ AD4-37 gene product is paired with a $L$ chain from one of a limited set of $V_{\lambda}$ gene rearrangements.

In the reciprocal chain shuffling studies, the $V_{L}$ AD4-37 gene was paired with the diverse $\mathrm{V}_{\mathrm{H}}$ gene rearrangement library from the affected SLE twin, AA. Again, panning successfully selected for Abs with dsDNA binding activity, and hybridization studies confirmed enrichment for the original partner gene $\mathrm{V}_{\mathrm{H}} \mathrm{AD} 4-37$ (Table III). Sequence analysis confirmed this selection, and also demonstrated an autoAb Fab clone, termed AAD4-HC2, that uses a distinct $\mathrm{V}_{\mathrm{H}} 3$ gene that appears to be derived from a separate germline gene segment,

Table II. DNA Hybridization Studies of Twin IgG Fab Libraries

\begin{tabular}{|c|c|c|c|c|c|c|c|c|c|c|}
\hline & $\mathrm{V}_{\mathrm{H}} 1^{*}$ & $\mathrm{~V}_{\mathrm{H}} 2$ & $\mathrm{~V}_{\mathrm{H}} 3$ & $\mathrm{~V}_{\mathrm{H}} 4$ & $\mathrm{~V}_{\mathrm{H}} 5$ & $\mathrm{~V}_{\mathrm{H}} 6$ & $\mathrm{AD} 4-37 \mathrm{~V}_{\mathrm{H}} \mathrm{CDR} 3$ & $\mathrm{AD} 4-18 \mathrm{~V}_{\mathrm{H}} \mathrm{CDR} 3$ & $\mathrm{AD} 4-37 \mathrm{~V}_{\mathrm{L}} \mathrm{CDR} 1^{\ddagger}$ & $\mathrm{AD} 4-37 \mathrm{~V}_{\mathrm{L}} \mathrm{CDR} 3$ \\
\hline \multicolumn{11}{|l|}{ AA libraries ${ }^{\S}$} \\
\hline Unselected & 11 & 0 & 10 & 31 & 42 & $<1$ & 2.4 & 1.4 & 5 & 2.4 \\
\hline Selected & 1.5 & 0 & 34 & 4 & 31 & 0 & $30^{\|}$ & $20^{\|}$ & 22 & $25^{\|}$ \\
\hline \multicolumn{11}{|l|}{ BB libraries } \\
\hline Unselected & 16 & 0 & 11 & 31 & 37 & $<1$ & 1.8 & $<1$ & 2 & 2 \\
\hline Selected ${ }^{\mathscr{T}}$ & 14 & 0 & 7 & 36 & 32 & $<1$ & $<0.5$ & $<1$ & 4 & $<0.5$ \\
\hline
\end{tabular}

* These data represent results of hybridization of membrane lifts of bacterial colonies with 150 to 250 colonies per plate for each $\mathrm{V}_{\mathrm{H}}$ gene probe, with subsequent stripping and reprobing with a constant region-specific probe. Data are presented as percentages of colonies that also hybridized with a $\mathrm{C} \gamma$-specific probe. Controls included in each study were plasmids with $\mathrm{V}_{\mathrm{H}}$ genes of all known families, or AD4-18 and AD4-37 plasmids. In each $\mathrm{V}_{\mathrm{H}}$ region survey certain colonies were unidentified, either because they did not contain $\mathrm{V}_{\mathrm{H}}$ genes or presumably because sequence variations abolished hybridization. Confirmation of reproducibility of values was confirmed by performance of each hybridization study at least twice. ${ }^{\ddagger}$ The values for the AD4-37 $\mathrm{V}_{\mathrm{L}}$-derived oligonucleotide hybridizations were calculated as the percentage of colonies that also hybridized with a $\mathrm{C} \lambda$-specific probe. Studies with a CDR1 sequence probe from $V_{L} A D 4-37$ demonstrated the same repesentation detected with the CDR3 probe from $V_{L} A D 4-37$. ${ }^{\S}$ The selected libraries were obtained after four sequential rounds of panning on wells precoated with dsDNA. Studies with oligonucleotide probe for the AD4$37 \mathrm{~V}_{\mathrm{H}}$ rearangement, $\mathrm{AD} 4-37 \mathrm{~V}_{\mathrm{H}} \mathrm{CDR}$ 3, display $>12$-fold enrichment in the selected AA library, and $>14$-fold enrichment with the $\mathrm{AD} 4-18 \mathrm{~V}_{\mathrm{H}}$ rearrangement probe, $A D 4-18 V_{H} C D R 3$. The oligonucleotide probe for the $A D 4-37 V_{L}$ rearrangement, $A D 4-37 V_{L} C D R 3$, displays 10 -fold enrichment in the selected AA library. "These values in the AA selected library are statistically significant in relation to the unselected library $(P<0.05)$ as determined by chi-square analysis, with the BB libraries used for the comparisons. ${ }^{1}$ Hybridization studies of the BB library after four rounds of panning against dsDNA did not detect a change in the $\mathrm{V}_{\mathrm{H}}$ family clonal distribution. 
Table III. DNA Hybridization Studies of Shuffled IgG Fab Libraries*

\begin{tabular}{|c|c|c|}
\hline & $\mathrm{AD} 4-37 \mathrm{~V}_{\mathrm{H}} \mathrm{CDR} 3 *$ & $\mathrm{AD} 4-37 \mathrm{~V}_{\mathrm{L}} \mathrm{CDR} 3$ \\
\hline \multicolumn{3}{|c|}{$\mathrm{V}_{\mathrm{H}} 4-37$ with AA L chain library } \\
\hline Unselected & & 2 \\
\hline Selected & & 9 \\
\hline \multicolumn{3}{|c|}{$\mathrm{V}_{\mathrm{H}} 4-37$ with $\mathrm{BB} L$ chain library } \\
\hline Unselected & & $<<1$ \\
\hline Selected & & $<<1$ \\
\hline \multicolumn{3}{|c|}{$V_{L} 4-37$ with AA $H$ chain library } \\
\hline Unselected & 0.8 & \\
\hline Selected & 6.4 & \\
\hline \multicolumn{3}{|c|}{$V_{L} 4-37$ with $B B H$ chain library } \\
\hline Unselected & $<<1$ & \\
\hline Selected & 0 & \\
\hline
\end{tabular}

* In each shuffled library, a H or L chain gene from the AD4-37 clone was paired with a diverse library of genes for the reciprocal chains from either the AA or BB library, as indicated. Hybridization studies were performed before (unselected) and after four rounds of panning with dsDNA (selected). In libraries with diverse chains from the AA library, panning enriched for representation of clones reactive with the probe for the original chain mate in the AD4-37 clone, while similar enrichment was not detected with pairing of genes from the BB library. Studies of shuffled libraries were performed and data compiled as described in Table IIII.

Cos6, but with a DNA sequence for the V-D-J rearrangement that is identical to that of $\mathrm{V}_{\mathrm{H}} \mathrm{AD} 4-37$. While it is uncertain whether this is an artifact that is due to "jumping" PCR, the selection of this rearrangement supports a central role for the $\mathrm{V}_{\mathrm{H}} \mathrm{CDR} 3$ subdomain in determining dsDNA binding activity (see below). Within this selected library, clones represented by another $\mathrm{V}_{\mathrm{H}} 3$ rearrangement, exemplified by the AAD4-3/3 Fab clone, were also recovered (Figs. 2 and 3).

A shuffled library of the $\mathrm{V}_{\mathrm{L}}$ AD4-37 gene paired with the diverse $\mathrm{V}_{\mathrm{H}}$ gene rearrangement library from the healthy twin, $\mathrm{BB}$, was also created. However, despite recurrent attempts, panning consistently failed to select for Abs with dsDNA binding activity, although ssDNA binding activity was often present (not shown)(G.J. Silverman, manuscript in preparation). These studies suggest that dsDNA binding activity stringently requires appropriate $\mathrm{V}_{\mathrm{H}}$ rearrangements that were not prevalent in the expressed repertoire of the healthy twin.

$V_{H} C D R 3$ sequence analysis of anti-DNA antibodies. Analyses of the CDR3 amino acid sequences of the dsDNA selected autoAbs demonstrated patterns previously demonstrated in anti-DNA autoAbs recovered from B cell lines. In Fig. 3, these $\mathrm{V}_{\mathrm{H}} \mathrm{CDR} 3$ all included arginines, and lysines and asparagines were also prominently represented, which have all previously been shown to contribute to DNA binding affinity (reviewed in reference 33). Only in the case of the AD4-18 could we detect homology with a $\mathrm{D}_{\mathrm{H}}$ segment (Fig. 3), which are often difficult to distinguish in adult human $\mathrm{V}_{\mathrm{H}}$ rearrangements (34).

$V_{L}$ sequence analysis of anti-DNA antibodies. The $\mathrm{V}_{\lambda}$ domains of all the cloned anti-dsDNA Abs included arginines and/or asparagines in at least two of the three CDR (Fig. 4). In к-type autoAbs, these same amino acids contribute to DNA binding specificity and affinity (35), however the role of $V_{\lambda}$ regions in DNA binding has not been systematically examined (36).

Anti-DNA antibodies, cross-reactivity, and fine binding specificity. Fab were evaluated for binding activity with ssDNA, dsDNA, and a panel of other types of Ags (Fig. 5). The AD4-37 auto $\mathrm{Ab}$ has virtually equal binding interactions with dsDNA and ssDNA (Fig. 5); it also binds dextran sulfate, ovalbumin, tetanus toxoid, and methyl-BSA, and the autoAg IgG Fc, but it does not bind cardiolipin or actin. This pattern of polyreactivity is also displayed by the anti-DNA Ab, KIM4.6, which has a $98 \%$ homologous $\mathrm{V}_{\mathrm{H}}$ gene segment, and is also paired with a germline $\lambda$-type $\mathrm{L}$ chain (37). In contrast, the AD4-18 autoAb has the reactivity pattern most commonly associated with high affinity IgG autoAbs (38). It binds to dsDNA and ssDNA near equally, and does not significantly react with other Ags.

The Abs from the shuffled libraries, ABD4-lam2, ABD4lam3, include the $\mathrm{H}$ chain of AD4-37 each with a different $\mathrm{L}$ chain. This alternate $\mathrm{L}$ chain pairing was associated with a pattern of binding similar to AD4-18, in which the dsDNA and ssDNA are recognized near equally while the other Ags were recognized weakly or not at all. The other Abs from the shuffled libraries, AAD4-HC2 and AAD4-3/3, include the L chain of AD4-37 each with a different $H$ chain. These Abs display the same monoreactivity with dsDNA and ssDNA, with little or no binding with the most of the other Ags, except that AAD4-3/3 has stronger binding with cardiolipin.

Idiotype expression on monoclonal anti-DNA antibodies. Based on the V gene usage of the IgG anti-DNA autoAbs obtained from the AA library and previously described SI library (11), studies were performed to evaluate the expression of three well characterized anti-idiotypic Abs specific for the $\mathrm{V}$ gene segments expressed within these autoAbs (Table I). The murine $\mathrm{IgG}_{1} \mathrm{mAb}, \mathrm{B} 6$, identifies the products of only $\sim 10 \%$ of known potentially functional germline $\mathrm{V}_{\mathrm{H}} 3$ gene segments $(18,19)$. These B6 CRI-associated genes include the 1.9III/ V3-30 gene, that encodes the $V_{H}$ AD4-37 from the AA twin library, and the highly homologous $\operatorname{Cos} 3$ gene that encodes the $\mathrm{V}_{\mathrm{H}} \mathrm{SI}-22$ and $\mathrm{V}_{\mathrm{H}} \mathrm{SI}-40$ anti-DNA Abs from the SI lupus library (Fig. 2 and Table I)(11).

As predicted by $\mathrm{V}$ gene usage, two nonoverlapping sets of the cloned IgG anti-dsDNA autoAbs expressed either the B6 or the 18/2 CRI (Table I). Confirming a recent report (25), the serologic reagent, murine monoclonal $\lambda$ IIIa, which recognizes a set within $V_{\lambda}$ III L chains (26), reacted with the AD4-37 Ab that has a $\mathrm{L}$ chain encoded by a near germline $\mathrm{V}_{\lambda}$ III.1 gene segment.

Serologic surveys of donors and other SLE patients. High titer $(>1: 640)$ antinuclear Abs were detected in both twins. However only the affected twin, AA, had Abs to native DNA as detected in a Crithidia assay (data not shown). In contrast, repeated serial serologic evaluations of the healthy twin, BB, have consistently failed to detect autoAbs reactive by Crithidia immunofluorescence. Of the sera from 36 SLE patients evaluated in a sensitive direct binding ELISA, 16 SLE patients (including the donors AA and SI) had significantly elevated levels of IgG dsDNA binding activity (Table IV). The elevated autoAb levels in these SLE patients were also above that detected for all 32 healthy controls. Of the SLE patients, the affected twin, AA, had one of the highest levels of IgG antidsDNA activity. Of interest, the level of IgG anti-ssDNA 


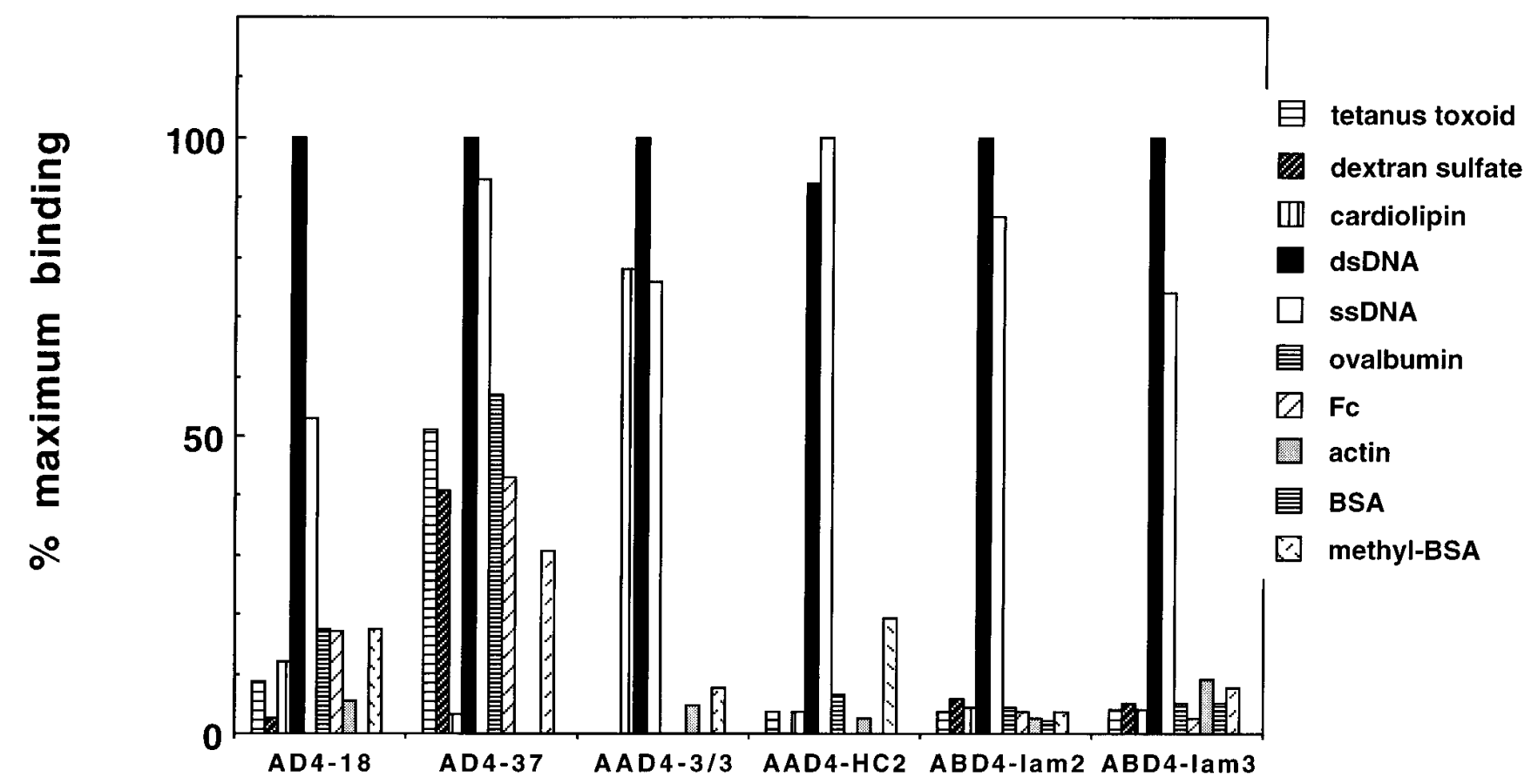

Figure 5. Cross-reactivities of Fabs to a panel of solid-phase antigens tested by ELISA. Reactivities are compared for each monoclonal IgG Fab at $2 \mu \mathrm{g} / \mathrm{ml}$. Values are reported as a percentage of the maximum absorbance attained, as previously described (11).

binding in the serum of the healthy twin was also above the range detected in the healthy controls (Table IV).

Idiotypic surveys of the SLE patients and normal controls. Assays of idiotype expression were designed to enable identification of the idiotype expressed on IgG autoAbs in the serum, but to avoid detection of the idiotype on the parallel set of Abs that do not possess autoreactivity. Of the 16 SLE sera with elevated levels of IgG anti-dsDNA Abs, six expressed the B6 CRI, four expressed the $\lambda$ IIIIa CRI and 10 expressed the $18 / 2$ CRI (Table IV). To simultaneously detect the CRI and Ig isotype of anti-dsDNA Abs, the design of the inhibition assays exploited the ability of these particular antiidiotypic Abs to inhibit the interaction between the autoAb and the Ag, dsDNA, indicating that each anti-CRI binds to a $\mathrm{V}$ region site at or near the DNA binding paratope. In these studies, the mAb B6 inhibited the IgG dsDNA binding in all six of the sera containing the corresponding idiotype (10-44\%). The mAb $\lambda$ IIIa inhibited the IgG dsDNA activity of two of the four sera positive for this idiotype (21 and 47\%). Ra504 inhibited IgG dsDNA binding of 3 of the 10 sera associated with the 18/2 idiotype (11-14\%). Isotype controls did not cause significant inhibition.

Inhibition of $\operatorname{IgM}$ anti-dsDNA auto Ab activity by the anti-Id demonstrated many cases of overlapping patterns of idiotypic expression between the IgM- and IgG-anti-dsDNA Abs (Table IV). However, for one SLE patient the $\lambda$ IIIIa idiotype, and for two patients the B6 idiotype, were only expressed on the IgG anti-dsDNA Abs. For three patients (which included the SI donor) the 18/2 idiotype inhibition was detected only on the IgG anti-dsDNA Abs, while in two other SLE patients inhibition was detected only in the IgM anti-dsDNA Abs. The common association of an idiotype with $\geq 10 \%$ of this auto $\mathrm{Ab}$ activity suggests that these responses are oligoclonal, and that antiidiotype recognition is not generally de- stroyed on IgG Abs by Ab V gene hypermutation. The examples of discordant idiotype expression on the $\operatorname{IgG}$ and $\operatorname{IgM}$ anti-dsDNA Abs may be related to B cell clonal shifts that accompany isotype switch in the autoimmune response.

Significantly, there was a complete concordance between the idiotypes expressed on the serum anti-DNA autoAbs of the donors and the monoclonal IgG Fab anti-dsDNA Abs derived from their respective libraries. In specific, the monoclonal IgG autoAbs from the SI lupus library expressed all three CRI as did her serum IgG anti-dsDNA autoAbs. The serum IgG autoAbs from the donor AA were associated with only the B6 and $\lambda$ IIIa idiotypes and not the 18/2 idiotype, representing the same pattern detected in her cloned autoAbs.

The above described $\mathrm{V}$ gene sequence analyses, and the $\mathrm{H}-\mathrm{L}$ chain-shuffling experiments, suggested that the generation of dsDNA binding activity in Abs with B6 idiotype-associated $\mathrm{H}$ chains requires specific pairing with certain $\lambda$-type $\mathrm{L}$ chains. To determine whether this restrictive $\mathrm{H}-\mathrm{L}$ chain pairing could be detected within the in vivo responses of SLE patients, we tested the ability of $\mathrm{mAb} B 6$ to inhibit $\kappa$ and $\lambda$ chainspecific dsDNA binding by serum Abs. In all six SLE sera with IgG anti-dsDNA Abs associated with the B6 idiotype, significant B6 inhibition (10-55\%) was detected in the $\lambda$ chain-associated dsDNA binding (not shown). In contrast, the B6 Ab did not inhibit $\kappa$ chain-associated dsDNA binding (not shown). The anti-18/2 CRI reagent and isotype controls did not significantly inhibit either $\kappa$ or $\lambda$ L chain-associated dsDNA binding (not shown).

To further evaluate whether the patterns of $\mathrm{H}-\mathrm{L}$ chain pairing in the autoAbs from the libraries are relevant to the in vivo response, we evaluated the inhibitory effect of adding two or three antiidiotypic reagents together to the same serum sample (Table V). Addition of the B6 and 18/2 specific anti- 


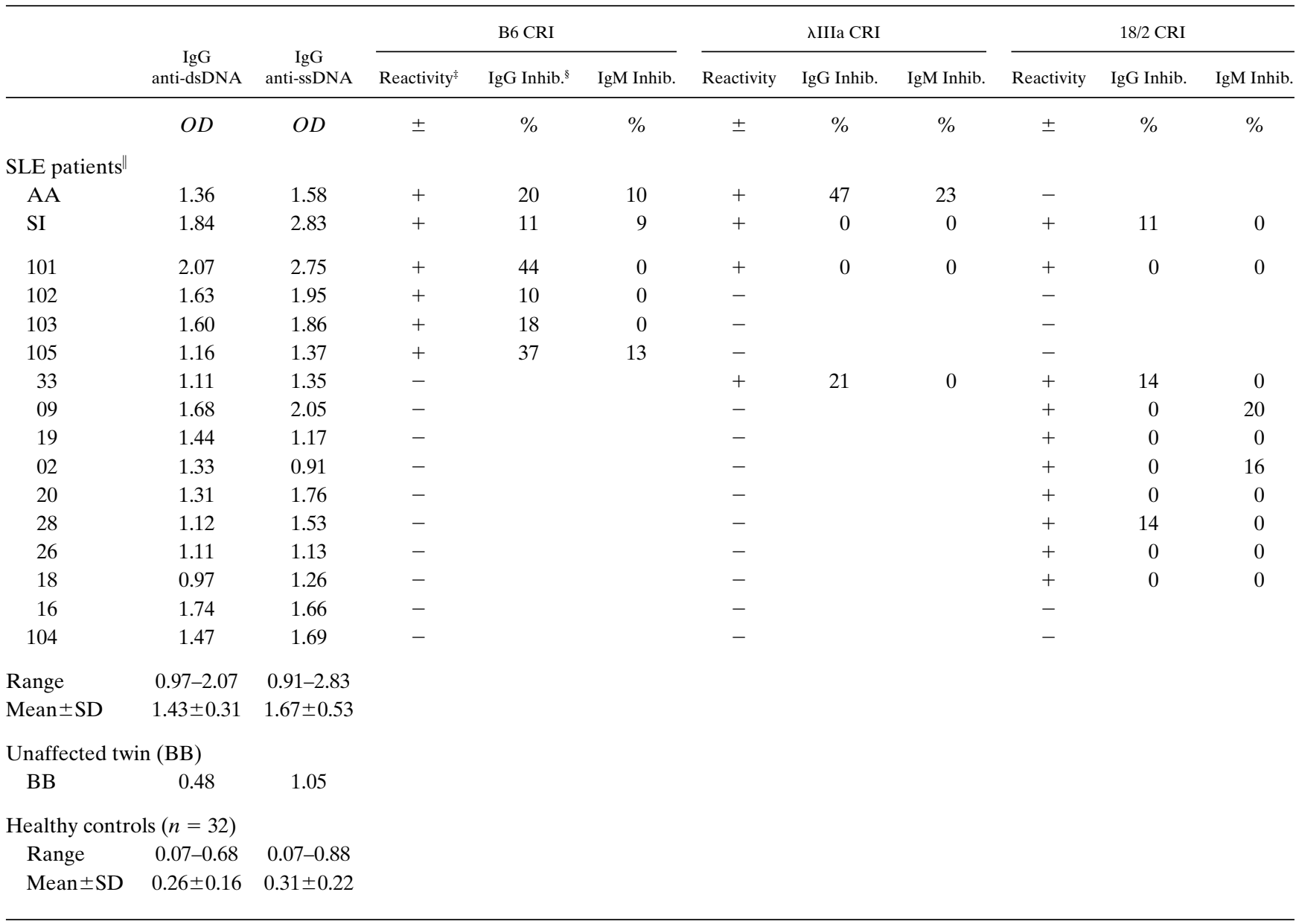

* The B6 CRI and the 18/2 CRI are present on nonoverlapping subsets of $\mathrm{V}_{\mathrm{H}} 3$ Ig. The $\lambda$ IIIIa CRI represents a subset of $\mathrm{V}_{\lambda}$ III Ig. The patients with B6 CRI on their anti-DNA Abs represent OD 0.18-0.81. The patients with $\lambda$ IIIIa CRI on their anti-DNA Abs represent OD 0.40-1.30. The patients with 18/2 CRI on their anti-DNA Abs represent OD 0.16-1.00. ${ }^{*}$ Reactivity represents the level of anti-dsDNA antibodies that are identified by each antiidiotypic antibody. +/- was designated based on whether the OD was $3 \mathrm{SD}$ above the background level for the assays of sera from healthy controls. ${ }^{\S}$ Inhibition studies were only performed for the sera with CRI reactive anti-dsDNA antibodies by sandwich ELISA (see Methods). For these assays, sera at a fixed dilution were preincubated with saturating concentrations of antiidiotypic Abs, then added to dsDNA-coated wells and later developed with either IgM or IgG-specific horseradish peroxidase tagged reagent, and then developed. Values were determined by comparison with standard curves of serial dilutions of each sera without inhibitor. For $\lambda$ IIIIa and B6 anti-idiotypic mAbs, equivalent studies using MOPC21 as the isotype control displayed $0-4 \%$ inhibition. For the anti-18/2 CRI, equivalent studies using rabbit IgG as the isotype control displayed $0-2 \%$ inhibition. ${ }^{\|}$Sera from individual SLE patients are indicated by letter or number code.

CRI reagents to serum SI resulted in additive inhibition, suggesting that the $\mathrm{V}_{\mathrm{H}^{-}}$associated $\mathrm{B} 6$ idiotype and the $\mathrm{V}_{\mathrm{H}^{-}}$-associated 18/2 idiotype are on separate sets of autoAbs molecules. However, when the B6 and $\lambda$ IIIa antiidiotypic Abs were added together to serum of the lupus twin, AA, inhibition was equal only to the effect of $\lambda$ IIIa alone, which individually caused greater inhibition than the $\mathrm{B} 6$ antiidiotypic $\mathrm{Ab}$. This result suggests that a large subset of the serum IgG anti-dsDNA autoAbs of the AA donor coexpress the B6 CRI on $\mathrm{H}$ chains paired with L chains that express the $\lambda$ IIIa CRI. Therefore,

Table V. Inhibition of Serum IgG Anti-ds DNA Antibody Activity by Antiidiotypic Antibodies

\begin{tabular}{|c|c|c|c|c|c|c|c|}
\hline SLE patient & B6 CRI* & $\lambda$ IIIIa CRI & 18/2 CRI & B6 CRI + $\lambda$ IIIa CRI & B6 CRI + 18/2 CRI & $\lambda$ IIIa CRI + 18/2 CRI & All three \\
\hline $\mathrm{AA}$ & $20 \%$ & $47 \%$ & - & $46 \%$ & $18 \%$ & $48 \%$ & $49 \%$ \\
\hline SI & $11 \%$ & $0 \%$ & $11 \%$ & $10 \%$ & $24 \%$ & - & $27 \%$ \\
\hline 101 & $44 \%$ & $0 \%$ & $0 \%$ & $44 \%$ & $43 \%$ & $0 \%$ & $40 \%$ \\
\hline 33 & - & $21 \%$ & $14 \%$ & $23 \%$ & $14 \%$ & $24 \%$ & $33 \%$ \\
\hline
\end{tabular}

* The percent inhibition of IgG anti-dsDNA binding capacity after preincubation with saturating concentrations of antiidiotypic antibodies. Studies were performed only if CRI was detected on anti-dsDNA antibodies by sandwich ELISA (see Methods). Values were determined by comparison with standard curves of serial dilutions of each sera without inhibitor. 
these data further support the impression that there is an equivalent pairing of idiotype reactive $\mathrm{H}$ and $\mathrm{L}$ chains in the serum of the SLE donor, AA, and in the IgG anti-dsDNA Abs from the AA library.

\section{Discussion}

In the current report, we have used repertoire cloning methods to sample Abs from in vivo lupus autoAb responses. While repertoire cloning strategies have been previously used in several studies to generate high affinity $\mathrm{mAbs}$ of a desired specificity, there has been concern regarding the suitability of this approach to investigate in vivo responses. A primary issue is the relationship between library-derived Abs and those constituting the response in vivo. Two studies in mouse models have attempted to directly evaluate this relationship, but the results led to different conclusions regarding whether the library approach enabled recovery of Abs with the same $V_{H}$ and $V_{L}$ genes sampled by the hybridoma approach $(39,40)$. While direct side-by-side comparisons of hybridomas and combinatorial library studies have not been feasible in humans, studies have documented that repertoire cloning approaches can isolate human Abs with Ag-binding properties identical to those of the donor's serum Abs to infectious pathogens (41, $42)$ and autoAgs $(43,44)$. In the current report, anti-dsDNA Abs were obtained from libraries from two lupus patients, and our sequence analyses and idiotype surveys indicate that these recovered autoAbs can use $\mathrm{V}$ regions with predominant $\mathrm{H}-\mathrm{L}$ combinations that reiterate features of the in vivo response (discussed further below). In contrast, multiple selection attempts using a suitable control library, a library from an identical twin discordant for disease, failed to recover anti-dsDNA autoAbs, a disease marker. These studies suggest that in this experimental system the de novo pairing of $\mathrm{H}$ and $\mathrm{L}$ chains unrelated to the in vivo autoimmune response did not create this high affinity disease-associated autoreactive binding specificity.

Studies of the B cell repertoires of identical twins discordant for lupus provide special opportunities. Due to their common genetic background, the differential representation of $\mathrm{Ab}$ genes in the IgG libraries from the twins must reflect somatic variations, presumably arising from different environmental exposures or from stochastic somatic processes such as those involved in $\mathrm{V}$ gene rearrangement. As a direct consequence, differences in the composition of these libraries are likely to be due to overrepresentation of certain activated B cells with higher Ig mRNA levels and/or underrepresentation due to hypermutation of $\mathrm{Ab}$ gene sequences that are targets for oligonucleotide-mediated amplification. For both of our twins, serologic studies demonstrated unusually high titers of antinuclear Abs, including high levels of IgM and IgG anti-ssDNA Abs (Table IV), suggesting they share an inherited predisposition to autoimmunity. However, other types of autoAbs were differentially expressed. Importantly, the affected twin had diagnostically high levels of IgG anti-dsDNA Abs, while the healthy twin had only Abs primarily to single stranded DNA that can represent "natural autoAbs" common in healthy individuals (45).

Analyses of the $V_{H}$ gene expression in each twin's IgG repertoire demonstrated nearly identical $\mathrm{V}_{\mathrm{H}}$ family distribution, which we speculate is due to a genetically controlled regulation of the composition of the primary repertoire. While the dominance of the larger $\mathrm{V}_{\mathrm{H}} 1, \mathrm{~V}_{\mathrm{H}} 3$, and $\mathrm{V}_{\mathrm{H}} 4$ families agrees with earlier reports $(30,31,46)$, we unexpectedly found that the small (two to three member) $\mathrm{V}_{\mathrm{H}} 5$ family was overexpressed $(\sim 37-42 \%)$ in the unselected libraries from both twins (47), while the $\mathrm{V}_{\mathrm{H}} 5$ family represented $<1 \%$ of the cloned repertoires of healthy adults evaluated with the same cloning methods (16)(unpublished observation) and with other approaches $(30,48,49)$.

While a special role for $\mathrm{V}_{\mathrm{H}}$ 5-expressing $\mathrm{B}$ cell clones in SLE pathogenesis has not been previously reported, the $\mathrm{V}_{\mathrm{H}} 5$ derived AD4-18 from the affected twin has the molecular features of a pathogenic autoAb. Of interest, this autoAb has three clustered mutations in two adjacent codons in a FR3 hot spot $(28,50)$ associated with the target DNA sequence, A/G$\mathrm{G}-\mathrm{C} / \mathrm{T}-\mathrm{A} / \mathrm{T}(51,52)$. Asparagine replacement mutations at this site have also been previously described in an $\mathrm{IgM}$ and an $\mathrm{IgG}_{3}$ murine anti-DNA hybridoma $(53,54)$ that use $\mathrm{V}_{\mathrm{H}} \mathrm{J} 558$ rearrangements that are highly homologous to this human $\mathrm{V}_{\mathrm{H}} 5$ gene. A molecular model predicted the direct involvement in DNA binding of this position within the auxiliary Ag binding loop, "HV4", of J558-encoded autoAbs (33), and experimental mutagenesis studies confirmed that creation of a basic amino acid at this site improved DNA binding affinity (55). These findings argue that targeted somatic hypermutation of a $\mathrm{V}_{\mathrm{H}} 5$ rearrangement is involved in the creation of disease-associated autoAbs in the SLE-affected twin.

Sequence analyses identified $\mathrm{V}_{\mathrm{H}}$ gene segments in the antiDNA Abs from our lupus libraries (Table I) that have all been previously described in anti-DNA autoAbs obtained by conventional cellular approaches (reviewed in reference 49). During the design of these studies, we had anticipated that, like the $\mathrm{V}_{\mathrm{H}}$ 5-derived AD4-18 Ab, all of the IgG anti-dsDNA autoAbs would display evidence of extensive hypermutation, that reflect affinity maturation and clonal selection in the periphery. Therefore, it was surprising that about half of these cloned autoAbs represented minimally mutated autoAbs, that all derive from distinct $\mathrm{V}_{\mathrm{H}} 3$ genes that have earlier been identified in nonmutated IgM anti-DNA autoAbs from B cell lines $(20,27)$. The idiotypic data document that related $\mathrm{H}$ chains are commonly part of the anti-dsDNA Ab response of many patients with SLE. While these same $\mathrm{V}_{\mathrm{H}} 3$ genes are also highly expressed in healthy individuals (56), equivalent $\mathrm{IgG}$ autoAbs could not be obtained from healthy individuals in identical selection experiments, as dsDNA binding activity appears to require specific V-D-J rearrangement patterns. Thus, although specific V-D-J rearrangements are required, extensive hypermutation is not essential for the in vivo development of all parental disease-associated autoreactive B cell clones.

The prevalence of these minimally mutated high affinity $\mathrm{IgG}$ anti-dsDNA autoAbs in the in vivo autoimmune response of patients with aggressive lupus nephritis supports current paradigms that defects in central B cell tolerance directly contribute to the pathogenesis of SLE. In health, a B cell clone with surface membrane expression of one of these autoAbs should be deleted (or anergized or receptor modified) before it could reach the periphery (reviewed in reference 57). If an AD4-37-expressing B cell gained access to sites of tissue damage in the periphery, it might act as a highly efficient Ag-presenting cell for the presentation of self-peptides from nucleoproteins (58), which might then recruit nucleoprotein-specific $\mathrm{T}$ cell help and expand the autoimmune response in a cascading loss of peripheral tolerance to nucleoproteins and physically associated self determinants (59-61). Speculatively, evi- 
dence that near germline $\mathrm{V}_{\mathrm{H}} 3$ anti-DNA Abs dominate SLE repertoires could be indirect evidence of the involvement of $B$ cell superantigens in the initiation or perpetuation of autoimmune disease, as we have recently demonstrated that antiDNA Abs encoded by these same $\mathrm{V}_{\mathrm{H}} 3$ gene segments commonly confer high affinity binding specificity for bacterial or endogenous B cell superantigens $(15,16,62)$.

Within our chain-shuffling experiments, we discovered that anti-DNA Abs could only be selected from libraries with $\mathrm{L}$ chains from the healthy twin if there were pairings with the $\mathrm{V}_{\mathrm{H}}$ 3-encoded AD4-37 $\mathrm{H}$ chain; similar autoAbs could not be recovered from the library pairing the AD4-37 L chain with diverse $\mathrm{H}$ chains from the healthy twin. The results indicate that the $\mathrm{H}$ chain in the AD4-37 autoAb from the affected twin dominates the DNA binding specificity. Consistent with evidence of restrictive $\mathrm{H}-\mathrm{L}$ chain pairing in lupus autoAbs from B cell lines $(26,27)$, our chain shuffling experiments and serologic surveys of lupus patients also documented that only a limited subset of $\lambda$-type $L$ chains can confer dsDNA binding activity to Abs that use $\mathrm{H}$ chains like the AD4-37.

In summary, our studies indicate that the phage display repertoire cloning approach can be an efficient and effective means for characterizing disease-associated $\mathrm{Ab}$ responses. While the specific Abs recovered by any method are strongly influenced by the selection methods used, the data suggest that the current recovery efforts are aided in part by the preferential representation in the $\mathrm{Ab}$ libraries of mRNA from in vivo expanded B cell clones. While not all lupus anti-DNA antibodies are probably directly involved in the pathogenesis of lupus nephritis, future studies may benefit from $\mathrm{Ab}$ selection on complex self-Ags, like nucleosomes, that may be the true in vivo autoimmune targets (63) and which may place greater structural limitations for the selection of appropriate Ag binding sites. Alternatively, selection methods that use glomerular sections or glomerular basement membranes, in formats that correlate with serologic markers of disease activity (64), may offer optimal means for the isolation of pathogenic lupus autoantibodies. Coselection with private idiotypes generated from the donor's serum Abs may also further improve the recovery of relevant cloned Abs, and provide greater confidence in the identification of natural $\mathrm{H}-\mathrm{L}$ chain pairs. Taken together, these methods have the potential to greatly advance our understanding of the pathogenesis of Ab-mediated autoimmune disease.

\section{Acknowledgments}

We thank Dr. Dennis Burton for advice and encouragement at all phases of the project. We acknowledge Dr. Minoru Sasano for assistance in the construction of the AA and BB libraries, Raymond Wagenknecht for his expert technical assistance, and Jayakar Nayak for his careful critique of the manuscript. We also thank Dr. R.A. Mageed for his generous gift of anti-idiotypic Abs.

This work was supported in part by National Institutes of Health (NIH) grants AI34001, K02AI01378, AR07567, CA10056, and AI31880. Computational analyses were aided by NIH National Center for Research Resources GCRC Grant M01 RR00833 to The Scripps Research Institute. G.J. Silverman was a Scholar of the Lupus Foundation of America, Inc., and is a recipient of Biomedical Sciences Awards from the Arthritis Foundation. A. Solomon is an American Cancer Society Clinical Research Professor.

\section{References}

1. Klinman, D.M. 1990. Polyclonal B cell activation in lupus-prone mice precedes and predicts the development of autoimmune disease. J. Clin. Invest. 86:1249-1254.

2. Klinman, D.M., R.A. Eisenberg, and A.D. Steinberg. 1990. Development of the autoimmune B cell repertoire in MRL-lpr/lpr mice. J. Immunol. 144:506-511.

3. Wallace, D.J., T. Podell, J. Weiner, J.R. Klinenberg, S. Forouzesh, and E.L. Dubois. 1981. Systemic lupus erythematosus-survival patterns. Experience with 609 patients. J. Am. Med. Assoc. 245:934-938.

4. Koffler, D., P.H. Schur, and H.G. Kunkel. 1967. Immunological studies concerning the nephritis of systemic lupus erythematosus. J. Exp. Med. 126: $607-624$.

5. Rothfield, N.F., and B.D. Stollar. 1967. The relation of immunoglobulin class, patterns of anti-nuclear antibody, and complement-fixing antibodies to DNA in sera from patients with systemic lupus erythematosus. J. Clin. Invest. 46:1785-1794.

6. Lefkowith, J.B., and G.S. Gilkeson. 1996. Review: Nephritogenic autoantibodies in lupus: Current concepts and continuing controversies. Arthritis Rheum. 39:894-903.

7. Madaio, M.P., and M.J. Shlomchik. 1996. Emerging concepts regarding B cells and autoantibodies in murine lupus nephritis. J. Am. Soc. Nephrol. 7: 387-396.

8. Raz, E., M. Brezis, E. Rosenmann, and D. Eilat. 1989. Anti-DNA antibodies bind directly to renal antigens and induce kidney dysfunction in the isolated perfused rat kidney. J. Immunol. 142:3076-3082.

9. Madaio, M.P., J. Carlson, J. Cataldo, A. Ucci, P. Migliorini, and O. Pankewycz. 1987. Murine monoclonal anti-DNA antibodies bind directly to glomerular antigens and form immune deposits. J. Immunol. 138:2883-2889.

10. Persson, M.A., R. Caothien, and D.R. Burton. 1991. Generation of diverse high-affinity human monoclonal antibodies by repertoire cloning. Proc. Natl. Acad. Sci. USA. 88:2432-2436.

11. Barbas, S.M., H.J. Ditzel, E.M. Salonen, W.P. Yang, G.J. Silverman, and D.R. Burton. 1995. Human autoantibody recognition of DNA. Proc. Natl. Acad. Sci. USA. 92:2529-2533.

12. Rubin, R.L., F.L. Tang, E.K. Chan, K.M. Pollard, G. Tsay, and E.M. Tan. 1986. IgG subclasses of autoantibodies in systemic lupus erythematosus, Sjogren's syndrome, and drug-induced autoimmunity. J. Immunol. 137:25282534

13. Barbas, C.F., A.S. Kang, R.A. Lerner, S.J. Benkovic, and K.D. Janda. 1991. Assembly of combinatorial antibody libraries on phage surfaces: the gene III site linkage of recognition and replication functions by assembling combinatorial antibody Fab libraries along phage surfaces. Proc. Natl. Acad. Sci. USA. 88:4363-4366.

14. Barbas, C.F. III, and R.A. Lerner. 1991. Combinatorial immunoglobulin libraries on the surface of phage (phabs): rapid selection of antigen-specific fabs. Methods (Orlando). 2:119.

15. Sasano, M., D.R. Burton, and G.J. Silverman. 1993. Molecular selection of human antibodies with an unconventional bacterial B cell superantigen. $J$. Immunol. 151:5822-5839.

16. Silverman, G.J., P. Roben, J.-P. Bouvet, and M. Sasano. 1995. Superantigen properties of a human sialoprotein involved in gut-associated immunity. $J$. Clin. Invest. 96:417-426.

17. Pisetsky, D.S., and C.F. Reich. 1994. The influence of DNA size on the binding of anti-DNA antibodies in the solid and fluid phase. Clin. Immunol. Immunopathol. 72:350-356.

18. Crowley, J.J., R.A. Mageed, G.J. Silverman, P.P. Chen, F. Kozin, R.A. Erger, R. Jefferis, and D.A. Carson. 1990. The incidence of a new human crossreactive idiotype linked to subgroup VHIII heavy chains. Mol. Immunol. 27:87-94.

19. Suleyman, S., K.M. Thompson, O. Forre, M. Sioud, I. Randen, R.A. Mageed, and J.B. Natvig. 1994. Three new cross-reacting idiotopes as markers for the products of two distinct human VH3 genes expressed in the early repertoire. Scand. J. Immunol. 40:681-690.

20. Dersimonian, H., R.S. Schwartz, K.J. Barrett, and B.D. Stollar. 1987. Relationship of human variable region heavy chain germ-line genes to genes encoding anti-DNA antibodies. J. Immunol. 139:486-501.

21. Chen, P.P., M.F. Liu, S. Sinha, and D.A. Carson. 1988. A 16/6 idiotypepositive anti-DNA antibody is encoded by a conserved VH. Arthritis Rheum 31:1429-1431.

22. Young, F., L. Tucker, D. Rubinstein, T. Guillaume, J. Andre-Schwartz, K.J. Barrett, R.S. Schwartz, and T. Logtenberg. 1990. Molecular analysis of a germ line-encoded idiotypic marker of pathogenic human lupus autoantibodies. J. Immunol. 145:2545-2553.

23. Dersimonian, H., K.P. McAdam, C. Mackworth-Young, and B.D. Stollar. 1989. The recurrent expression of variable region segments in human $\operatorname{IgM}$ anti-DNA autoantibodies. J. Immunol. 142:4027-4033.

24. Abe, M., T. Goto, S.J. Kennel, D. Wolfenbarger, S.D. Macy, D.T. Weiss, and A. Solomon. 1993. Production and immunodiagnostic applications of antihuman light chain monoclonal antibodies. Am. J. Clin. Pathol. 100:67-74.

25. Ermel, R.W., T.P. Kenny, A. Wong, A. Solomon, P.P. Chen, and D.L. Robbins. 1994. Preferential utilization of a novel V lambda 3 gene in monoclonal rheumatoid factors derived from the synovial cells of rheumatoid arthri- 
tis patients. Arthritis Rheum. 37:860-868.

26. Harmer, I.J., S. Loizou, K.M. Thompson, A.K. So, M.J. Walport, and C. Mackworth-Young. 1995. A human monoclonal antiphospholipid antibody that is representative of serum antibodies and is germline encoded. Arthritis Rheum. 38:1068-1076.

27. Cairns, E., P.C. Kwong, V. Misener, P. Ip, D.A. Bell, and K.A. Siminovitch. 1989. Analysis of variable region genes encoding a human anti-DNA antibody of normal origin: Implications for the molecular basis of human autoimmune responses. J. Immunol. 143:685-691.

28. Cai, J., C. Humphries, A. Richardson, and P.W. Tucker. 1992. Extensive and selective mutation of a rearranged VH5 gene in human B cell chronic lymphocytic leukemia. J. Exp. Med. 176:1073-1081.

29. Bernard, F., P. Chuchana, J.-P. Frippiat, L. Bulewala, and M.-P. Lefranc. 1990. Genomic sequence of IGLV1S2, a human immunoglobulin variable lambda gene belonging to subgroup I. Nucleic Acids Res. 18:7139.

30. Huang, C., and B.D. Stollar. 1993. A majority of Ig H chain cDNA of normal human adult blood lymphocytes resembles cDNA for fetal Ig and natural autoantibodies. J. Immunol. 151:5290-5300.

31. Huang, C., A.K. Stewart, R.S. Schwartz, and B.D. Stollar. 1992. Immunoglobulin heavy chain gene expression in peripheral blood B lymphocytes. $J$. Clin. Invest. 89:1331-1343.

32. Paul, E., A.A. Iliev, A. Livneh, and B. Diamond. 1992. The anti-DNAassociated idiotype 8.12 is encoded by the VlambdaII gene family and maps to the vicinity of the L chain CDR1. J. Immunol. 149:3588-3595.

33. Radic, M.Z., and M. Weigert. 1994. Genetic and structural evidence for antigen selection of anti-DNA antibodies. Annu. Rev. Immunol. 12:487-520.

34. Sanz, I. 1991. Multiple mechanisms participate in the generation of diversity of human H chain CDR3 regions. J. Immunol. 147:1720-1729.

35. Ibrahim, S.M., M. Weigert, C. Basu, J. Erikson, and M.Z. Radic. 1995. Light chain contribution to specificity in anti-DNA antibodies. J. Immunol. 155: 3223-3233.

36. Chothia, C., and A.M. Lesk. 1987. Canonical structures for the hypervariable regions of immunoglobulins. J. Mol. Biol. 196:901-917.

37. Bell, D.A., E. Cairns, K. Cikalo, V. Ly, J. Block, and W. Pruzanski. 1987. Antinucleic acid autoantibody responses of normal human origin. $J$. Rheumatol. 14 (Suppl). 13:127-131.

38. Winkler, T.H., S. Jahn, and J.R. Kalden. 1991. IgG human monoclonal anti-DNA autoantibodies from patients with systemic lupus erythematosus. Clin. Exp. Immunol. 85:379-385.

39. Gherardi, E., and C. Milstein. 1992. Original and artificial antibodies. Nature (Lond.). 357:201-202.

40. Caton, A.J., and H. Koprowski. 1990. Influenza virus hemagglutininspecific antibodies isolated from a combinatorial expression library are closely related to the immune response of the donor. Proc. Natl. Acad. Sci. USA. 87: 6450 .

41. Barbas, C.F., T.A. Collet, W. Amberg, P. Roben, J.M. Binley, D. Hoekstra, D. Cababa, T.M. Jones, R.A. Williamson, and G.R. Pilkington. 1993. Molecular profile of an antibody response to HIV-1 as probed by combinatorial libraries. J. Mol. Biol. 230:812-823.

42. Williamson, R.A., R. Burioni, P.P. Sanna, L.J. Partridge, C.F. Barbas, and D.R. Burton. 1993. Human monoclonal antibodies against a plethora of viral pathogens from single combinatorial libraries. Proc. Natl. Acad. Sci. USA. 90:4141-4145.

43. Portolano, S., S.M. McLachlan, and B. Rapoport. 1993. High affinity, thyroid-specific human autoantibodies displayed on the surface of filamentous phage use V genes similar to other autoantibodies. J. Immunol. 151:2839-2851.

44. Hexham, J.M., J. Furmaniak, C. Pegg, D.R. Burton, and B.R. Smith. 1992. Cloning of a human autoimmune response: preparation and sequencing of a human anti-thyroglobulin autoantibody using a combinatorial approach. Autoimmunity. 12:135-141.
45. Izui, S. 1977. Mechanism for induction of anti-DNA antibodies by bacterial lipopolysaccharides in mice. J. Immunol. 119:2157-2162.

46. Logtenberg, T., M.E. Schutte, G. Inghirami, J.E. Berman, F.H. GmeligMeyling, R.A. Insel, D.M. Knowles, and F.W. Alt. 1989. Immunoglobulin VH gene expression in human B cell lines and tumors: biased $\mathrm{VH}$ gene expression in chronic lymphocytic leukemia. Int. Immunol. 1:362-366.

47. Berman, J.E., S.J. Mellis, R. Pollock, C.L. Smith, H. Suh, B. Heinke, C. Kowal, U. Surti, L. Chess, and C.R. Cantor. 1988. Content and organization of the human Ig VH locus: definition of three. EMBO (Eur. Mol. Biol. Organ.) J. 7:727-738.

48. Stewart, A.K., C. Huang, B.D. Stollar, and R.S. Schwartz. 1993. Highfrequency representation of a single VH gene in the expressed human. J. Exp. Med. 177:1227.

49. Stewart, A.K., C. Huang, A.A. Long, B.D. Stollar, and R.S. Schwartz. 1992. VH-gene representation in autoantibodies reflects the normal human B-cell repertoire. Immunol. Rev. 128:101-122.

50. Ebeling, S.B., M.E. Schutte, and T. Logtenberg. 1993. Peripheral human CD5+ and CD5- B cells may express somatically mutated VH5- and VH6encoded IgM receptors. J. Immunol. 151:6891-6899.

51. Rogozin, I.B., and N.A. Kolchanov. 1992. Somatic hypermutagenesis in immunoglobulin genes. II. Influence of neighboring base sequences on mutagenesis. Biochim. Biophys. Acta. 1171:11-18.

52. Yelamos, J., N. Klix, B. Goyenechea, F. Lozano, Y.L. Chui, A. Gonzalez-Fernandez, R. Pannell, M.S. Neuberger, and C. Milstein. 1995. Somatic hypermutation can efficiently target non-immunoglobulin sequences in place of the V segment. Nature (Lond.). 376:225-229.

53. Tillman, D.M., N.T. Jou, R.J. Hill, and T.N. Marion. 1992. Both IgM and IgG anti-DNA antibodies are the products of clonally selective B cell stimulation in $(\mathrm{NZB} \times \mathrm{NZW}) \mathrm{F} 1$ mice. J. Exp. Med. 176:761-779.

54. Radic, M.Z., M.A. Mascelli, J. Erikson, H. Shan, M. Shlomchik, and M. Weigert. 1989. Structural patterns in anti-DNA antibodies from MRL/lpr mice. Cold Spring Harbor Symp. Quant. Biol. 54:933-946.

55. Radic, M.Z., J. Mackle, J. Erikson, C. Mol, W.F. Anderson, and M. Weigert. 1993. Residues that mediate DNA binding of autoimmune antibodies. J. Immunol. 150:4966-4977.

56. Hufnagle, W.O., S.-C. Huang, I. Suzuki, and E.C.B. Milner. 1995. A complete preimmune human VH3 repertoire. Ann. NY Acad. Sci. 764:293-295.

57. Goodnow, C.C., J.G. Cyster, S.B. Hartley, S.E. Bell, M.P. Cooke, J.I. Healy, S. Akkaraju, J.C. Rathmell, S.L. Pogue, and K.P. Shokat. 1995. Self-tolerance checkpoints in B lymphocyte development. Adv. Immunol. 59:279-368.

58. Mamula, M.J., and C.A.J. Janeway. 1993. Do B cells drive the diversification of immune responses? Immunol. Today. 14:151-152.

59. Lehmann, P.V., E.E. Sercarz, T. Forsthuber, C.M. Dayan, and G. Gammon. 1993. Determinant spreading and the dynamics of the autoimmune T-cell repertoire. Immunol. Today. 14:203-208.

60. Rosen, A., L. Casciola-Rosen, and J. Ahearn. 1995. Novel packages of viral and self-antigens are generated during apoptosis. J. Exp. Med. 181:15571561.

61. Mamula, M.J., S. Fatenejad, and J. Craft. 1994. B cells process and present lupus autoantigens that initiate autoimmune T cell responses. J. Immunol. 152:1453-1461.

62. Roben, P., A. Salem, and G.J. Silverman. 1995. $\mathrm{V}_{\mathrm{H}} 3$ antibodies bind domain D of staphylococcal protein A. J. Immunol. 154:6437-6446.

63. Burlingame, R.W., M.L. Boey, G. Starkebaum, and R.L. Rubin. 1994. The central role of chromatin in autoimmune responses to histones and DNA in systemic lupus erythematosus. J. Clin. Invest. 94:184-192.

64. Bernstein, K.A., L.E. Kahl, J.E. Balow, and J.B. Lefkowith. 1994. Serologic markers of lupus nephritis in patients: use of a tissue-based ELISA and evidence for immunopathogenic heterogeneity. Clin. Exp. Immunol. 98:60-65. 